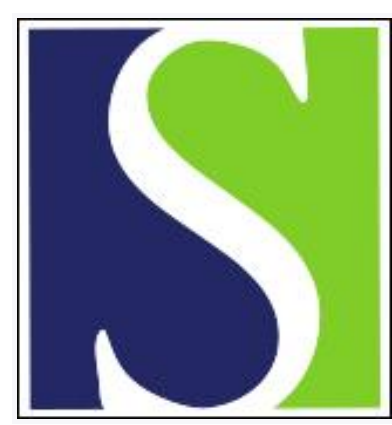

Scand J Work Environ Health 1981;7(2):119-130

https://doi.org/10.5271/sjweh.2557

Issue date: Jun 1981

Relation of soft-tissue sarcoma, malignant lymphoma and colon cancer to phenoxy acids, chlorophenols and other agents.

by Hardell $\mathrm{L}$

Key terms: agent; cancer; case-control design; case-referent design; chlorophenol; colon cancer; malignant lymphoma; phenoxy acid; soft-tissue sarcoma

This article in PubMed: www.ncbi.nlm.nih.gov/pubmed/7313616

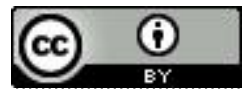




\title{
Relation of soft-tissue sarcoma, malignant lymphoma and colon cancer to phenoxy acids, chlorophenols and other agents
}

\author{
by Lennart Hardell, MD ${ }^{1}$
}

\begin{abstract}
HARDELL L. Relation of soft-tissue sarcoma, malignant lymphoma and colon cancer to phenoxy acids, chlorophenols and other agents. Scand $j$ work environ health 7 (1981) 119-130. An association between exposure to phenoxy acids or chlorophenols and softtissue sarcoma and malignant lymphoma has previously been reported. An association between exposure to organic solvents and malignant lymphoma has been demonstrated as well. In the present investigation the validity of the assessment of exposure to phenoxy acids and chlorophenols in the previous studies has been further analyzed, partly through a reconsideration of original data and partly through the utilization of another cancer type (colon cancer) for comparison. No observational bias was found which could distort the earlier findings. No significant association was found for these chemicals and colon cancer, whereas exposure to asbestos showed about a twofold increase in risk for colon cancer, an ocurrence in agreement with previously reported findings.
\end{abstract}

Key terms: case-referent (case-control) design, chlorophenols, colon cancer, malignant lymphoma, phenoxy acids, soft-tissue sarcoma.

An association between exposure to phenoxy acids or chlorophenols and softtissue sarcomas has recently been reported in two case-referent (case-control) studies $(4,11)$. A similar matched case-referent study of patients with malignant lymphoma (Hodgkin's disease and nonHodgkin lymphoma) indicated an association also between that disease and exposure to phenoxy acids or chlorophenols, but also to organic solvents (10). The background for these studies was clinical observations that might suggest a relationship $(8,9)$.

\section{Methodological features and concerns of previous studies}

Each of the three case-referent studies was designed to minimize the likelihood of spurious or misleading results and to en-

\footnotetext{
1 Department of Oncology, University Hospital, Umeå, Sweden.
}

Reprints requests to: Dr Lennart Hardell, Department of Oncology, University Hospital, S-901 85 Umeå, Sweden. able a meaningful evaluation of the risks associated with the exposures studied. In the first soft-tissue sarcoma study (11) and in the lymphoma study (10) the cases consisted of all the individuals with a histopathologically verified diagnosis who had been admitted to the Department of Oncology in Umeå during specified study periods. Cases in the second soft-tissue sarcoma study (4) were obtained from the Cancer Register of the Swedish Social Welfare Board, and they were all the patients residing in a particular region of southern Sweden at the time of diagnosis.

Referents were selected through a matching procedure, ie, they were selected individually to each case for sex (males only included), age, and place of residence. In addition, for deceased patients, deceased referents with the same year of death were selected.

In each of the studies, exposure information was obtained with written questionnaires and was supplemented by telephone interviews. With such a method care must be taken to avoid the possibility that the individuals' attitudes and previous ex- 
periences can introduce bias into the assessment of exposure (1). One possibility could be a tendency, conscious or not, for those suffering from a disease to overstate past exposure as compared to healthy referents. Each study was designed to minimize such recall bias through the inclusion of a number of questions about various occupational exposures.

Each subject, or the next-of-kin of a deceased subject, was mailed a questionnaire which consisted of nine pages with a variety of questions concerning previous and present occupation, conditions in the work environment, smoking habits, etc, or in total 33 different questions. Each question was subdivided into issues about special aspects of work conditions, exposure to different agents, etc, ie, about 130 questions in all. Ten of these subquestions were somehow related to the use of herbicides. This number is to be compared with, for example, 16 questions about the use of organic solvents, 4 about work with plastics, 3 about work with glues, 4 about use of drugs, and several questions about smoking habits. Supplementary interviews were carried out by individuals who did not know whether the subjects were cases or referents. Employers, neighbors, and other individuals who might have special knowledge concerning a subject's past exposure were consulted by the interviewer, if necessary, to verify and monitor the accuracy of the exposure information. Since deceased referents were selected for deceased patients, it is unlikely that there should be differences between the cases and referents because of differences in recall of exposure.

Despite all these efforts concerning the design of the studies, some observational bias might still exist. The purpose of the present investigation was to analyze further the validity of the assessment of exposure to phenoxy acids and chlorophenolls in the previous studies, partly through a reconsideration of the original data in these studies and partly through the utilization of another cancer type (colon cancer) both as an index series and as a reference for the earlier case series of soft-tissue sarcomas and malignant lymphomas. As already mentioned, the interviewers were blinded in all the studies. It has been suggested (3), however, that some cases might have revealed their disease during the phone call; if so, observational bias might have been introduced. For the evaluation of such a hypothetical possibility influencing the results in these studies, the exposure data based on the questionnaires only were compared to the exposure data obtained from the combined information from the phone interviews and the questionnaires.

\section{Material and methods}

\section{Reconsideration of earlier data and the} aims of the present study

In the previous studies $(4,10)$ the subjects were divided into the occupational categories agriculture/forestry and other. Risk ratios were then calculated within these occupations for both exposed and nonexposed individuals. For the nonexposed cases the risk ratios were 1.1 and 0.9 , respectively, in these studies, values which would be inconsistent with the occurrence of an observational bias in the assessment of exposure (1). Since it has been suggested that occupations were reported secondarily to the recall of exposure (3) however, the material has now also been further analyzed by subdividing the individuals occupied in agriculture/forestry into two groups, those who had been occupied in the same job throughout the whole period since 1950 (approximately when phenoxy acids were introduced in Sweden) and those who had been occupied for shorter periods and not continuously since 1950 . This subdivision rules out the possibility that occupation was reported secondarily to the recall of exposure as far as those occupied only in agriculture/forestry are concerned.

The cases in the present new study consisted of male patients with colon cancer, a disease not previously suspected to be associated with exposure to phenoxy acids or chlorophenols. The debate about phenoxy acids and their presumptive risks was intense in Sweden during the period when this new study was conducted. Accordingly, any systematic bias in the observation of exposure that might have been present in the first three studies should also be present in this study. 
Additional subjects with regard to colon cancer

Cases. The cases consisted of all male patients with colon cancer aged $25-85$ a who were residents in the region of the Department of Oncology, Umeå, and who had been reported to the Swedish Cancer Register in 1978-1979. They all had the histopathological diagnosis of adenocarcinoma.
Referents. All the referents in the two earlier studies in the Umeå region $(10,11)$ were used as the reference entity in the colon cancer study. Consequently both cases and referents were derived from the same population source. The information previously obtained from the questionnaires and interviews of these referents were thereby used and analyzed. Stratification was made for age and place of residence (rural or urban domicile).

Table 1. Exposure frequencies $(\%)$ to phenoxy acids on the basis of the questionnaires in three casereferent studies: I = soft-tissue sarcoma study I (11), II = soft-tissue sarcoma study II (4), and III = malignant lymphoma study (10). Data are shown for all exposure and with exposure to phenoxy acids within a latency period of 5 a or less than $1 \mathrm{~d}$ excluded.

\begin{tabular}{|c|c|c|c|c|c|c|}
\hline & \multicolumn{3}{|c|}{ All phenoxy acid exposure } & \multicolumn{3}{|c|}{$\begin{array}{l}\text { Phenoxy acid exposure within } \\
5 \text { a prior to the diagnosis or } \\
\text { of less than } 1 \text { d excluded }\end{array}$} \\
\hline & $\mathbf{I}$ & II & III & 1 & II & III \\
\hline $\begin{array}{l}\text { Cases } \\
\text { Referents }\end{array}$ & $\begin{array}{l}28.8 \\
13.6\end{array}$ & $\begin{array}{r}16.4 \\
4.6\end{array}$ & $\begin{array}{l}27.2 \\
11.0\end{array}$ & $\begin{array}{r}28.8 \\
8.7\end{array}$ & $\begin{array}{r}13.6 \\
2.7\end{array}$ & $\begin{array}{r}24.9 \\
7.5\end{array}$ \\
\hline $\begin{array}{l}\chi^{2}(1) \\
\text { Risk ratio }\end{array}$ & $\begin{array}{l}6.9 \\
2.6\end{array}$ & $\begin{array}{r}13.0 \\
4.1\end{array}$ & $\begin{array}{r}21.3 \\
3.0\end{array}$ & $\begin{array}{r}15.0 \\
4.2\end{array}$ & $\begin{array}{r}14.5 \\
5.6\end{array}$ & $\begin{array}{r}29.4 \\
4.1\end{array}$ \\
\hline
\end{tabular}

Table 2. Number of cases and referents exposed to phenoxy acids divided by occupation in the soft-tissue sarcoma study (4).

\begin{tabular}{|c|c|c|c|c|c|c|c|c|c|}
\hline & \multicolumn{6}{|c|}{ Agriculture/ forestry } & \multirow{2}{*}{\multicolumn{3}{|c|}{ Other occupations }} \\
\hline & \multicolumn{3}{|c|}{ Whole period since 1950} & \multicolumn{3}{|c|}{ Some period since 1950} & & & \\
\hline & $\begin{array}{l}\text { Phen- } \\
\text { oxy } \\
\text { acids }\end{array}$ & $\begin{array}{c}\text { Chlo- } \\
\text { ro- } \\
\text { phe- } \\
\text { nois }\end{array}$ & $\begin{array}{l}\text { Non- } \\
\text { ex- } \\
\text { posed }\end{array}$ & $\begin{array}{l}\text { Phen- } \\
\text { oxy } \\
\text { acids }\end{array}$ & $\begin{array}{l}\text { Chlo- } \\
\text { ro- } \\
\text { phe- } \\
\text { nols }\end{array}$ & $\begin{array}{c}\text { Non- } \\
\text { ex- } \\
\text { posed }\end{array}$ & $\begin{array}{l}\text { Phen- } \\
\text { oxy } \\
\text { acids }\end{array}$ & $\begin{array}{c}\text { Chlo- } \\
\text { ro- } \\
\text { phe- } \\
\text { nols }\end{array}$ & $\begin{array}{c}\text { Non- } \\
\text { ex- } \\
\text { posed }\end{array}$ \\
\hline $\begin{array}{l}\text { Cases } \\
\text { Referents }\end{array}$ & $\begin{array}{r}10 \\
3\end{array}$ & $\begin{array}{l}0 \\
0\end{array}$ & $\begin{array}{r}8 \\
17\end{array}$ & $\begin{array}{l}3 \\
2\end{array}$ & $\begin{array}{l}1 \\
3\end{array}$ & $\begin{array}{r}9 \\
22\end{array}$ & $\begin{array}{l}1 \\
0\end{array}$ & $\begin{array}{r}10 \\
5\end{array}$ & $\begin{array}{r}68 \\
167\end{array}$ \\
\hline \multirow[t]{4}{*}{ Risk ratio } & 8.2 & - & 1.2 & 3.7 & - & 1.0 & - & - & $(1.0)$ \\
\hline & \multicolumn{6}{|c|}{ Agriculture/forestry/woodwork } & \multirow{2}{*}{\multicolumn{3}{|c|}{ Other occupations }} \\
\hline & \multicolumn{3}{|c|}{ Whole period since 1950} & \multicolumn{3}{|c|}{ Some period since 1950} & & & \\
\hline & $\begin{array}{l}\text { Phen- } \\
\text { oxy- } \\
\text { acids }\end{array}$ & $\begin{array}{c}\text { Chlo- } \\
\text { ro- } \\
\text { phe- } \\
\text { nols }\end{array}$ & $\begin{array}{c}\text { Non- } \\
\text { ex- } \\
\text { posed }\end{array}$ & $\begin{array}{l}\text { Phen- } \\
\text { oxy- } \\
\text { acids }\end{array}$ & $\begin{array}{l}\text { Chlo- } \\
\text { ro- } \\
\text { phe- } \\
\text { nols }\end{array}$ & $\begin{array}{c}\text { Non- } \\
\text { ex- } \\
\text { posed }\end{array}$ & $\begin{array}{l}\text { Phen- } \\
\text { oxy- } \\
\text { acids }\end{array}$ & $\begin{array}{c}\text { Chlo- } \\
\text { ro- } \\
\text { phe- } \\
\text { nols }\end{array}$ & $\begin{array}{c}\text { Non- } \\
\text { ex- } \\
\text { posed }\end{array}$ \\
\hline $\begin{array}{l}\text { Cases } \\
\text { Referents }\end{array}$ & $\begin{array}{r}10 \\
3\end{array}$ & $\begin{array}{l}3 \\
3\end{array}$ & $\begin{array}{r}9 \\
19\end{array}$ & $\begin{array}{l}4 \\
2\end{array}$ & $\begin{array}{l}4 \\
4\end{array}$ & $\begin{array}{l}10 \\
27\end{array}$ & $\begin{array}{l}0 \\
0\end{array}$ & $\begin{array}{l}4 \\
1\end{array}$ & $\begin{array}{r}66 \\
160\end{array}$ \\
\hline Risk ratio & 8.1 & & 1.1 & 4.8 & & 0.9 & & & $(1.0)$ \\
\hline
\end{tabular}


Assessment of exposure. The procedure already described was used in the assessment of exposure for the colon cancer cases. The cases were mailed a questionnaire identical to the one previously used with a variety of questions about different workplaces, chemical exposures, use of drugs, smoking habits, etc. The answers were then, if necessary, completed over the phone by an interviewer who was not aware of whether the interviewee was a colon cancer patient or another subject since the quiestionnaires were mixed with identical questionnaires used in a simultaneous case-referent study of nasopharyngeal carcinoma (results to be published).

As in the previous studies the following criteria were used in the assessment of exposure. Subjects with a total exposure of less than $1 \mathrm{~d}$ to phenoxy acids were considered nonexposed in the analysis. Exposure to chlorophenols or organic solvents for less than one month over the years or less than one week continuously was considered low-grade; higher durations were termed high-grade. Exposure to phenoxy acids, chlorophenols, or organic solvents within 5 a prior to the diagnosis was not included, ie, exposure 1973 or later in this study, in the analysis of cases and referents just as in the earlier studies. For other agents analyzed no such exclusion was made.

\section{Statistical methods}

The statistical analysis of the data was based on the Mantel-Haenszel procedures for the calculation of $p$-values and for the estimation of overall rate ratio (16). The principles for determining standardized rate ratios have been outlined by Miettinen $(17,18)$, just as the method for calculating the confidence interval of the rate ratio (19).

\section{Results}

\section{Reconsideration of earlier data}

The analysis of the data in the questionnaires prior to the interviews concerning spraying operations with phenoxy acids is shown in table 1 . The risk ratios were calculated without any consideration of latency period or exposure time but also with exposure to phenoxy acids within the latency period of 5 a or less than $1 \mathrm{~d}$ excluded. In the analysis of exposure no consideration was given to matters dis-

Table 3. Number of cases and referents exposed to phenoxy acids divided by occupation in the malignant lymphoma study (10).

\begin{tabular}{|c|c|c|c|c|c|c|c|c|c|}
\hline & \multicolumn{6}{|c|}{ Agriculture/forestry } & \multirow{2}{*}{\multicolumn{3}{|c|}{$\begin{array}{l}\text { Other occupations/ } \\
\text { leisure time }\end{array}$}} \\
\hline & \multicolumn{3}{|c|}{ Whole period since 1950} & \multicolumn{3}{|c|}{ Some period since 1950} & & & \\
\hline & $\begin{array}{l}\text { Phen- } \\
\text { oxy } \\
\text { acids }\end{array}$ & $\begin{array}{l}\text { Chlo- } \\
\text { ro- } \\
\text { phe- } \\
\text { nols }\end{array}$ & $\begin{array}{l}\text { Non- } \\
\text { ex- } \\
\text { posed }\end{array}$ & $\begin{array}{l}\text { Phen- } \\
\text { oxy } \\
\text { acids }\end{array}$ & $\begin{array}{l}\text { Chlo- } \\
\text { ro- } \\
\text { phe- } \\
\text { nols }\end{array}$ & $\begin{array}{c}\text { Non- } \\
\text { ex- } \\
\text { posed }\end{array}$ & $\begin{array}{l}\text { Phen- } \\
\text { oxy } \\
\text { acids }\end{array}$ & $\begin{array}{l}\text { Chlo- } \\
\text { ro- } \\
\text { phe- } \\
\text { nols }\end{array}$ & $\begin{array}{c}\text { Non- } \\
\text { ex- } \\
\text { posed }\end{array}$ \\
\hline $\begin{array}{l}\text { Cases } \\
\text { Referents }\end{array}$ & $\begin{array}{l}27 \\
14\end{array}$ & $\begin{array}{l}2 \\
1\end{array}$ & $\begin{array}{l}21 \\
70\end{array}$ & $\begin{array}{l}8 \\
9\end{array}$ & $\begin{array}{l}3 \\
0\end{array}$ & $\begin{array}{l}16 \\
44\end{array}$ & $\begin{array}{l}6 \\
1\end{array}$ & $\begin{array}{r}15 \\
7\end{array}$ & $\begin{array}{r}71 \\
189\end{array}$ \\
\hline \multirow[t]{4}{*}{ Risk ratio } & 5.1 & - & 0.8 & 2.4 & - & 1.0 & - & - & $(1.0)$ \\
\hline & \multicolumn{6}{|c|}{ Agriculture/forestry/woodwork } & \multirow{2}{*}{\multicolumn{3}{|c|}{ Other occupations }} \\
\hline & \multicolumn{3}{|c|}{ Whole period since 1950} & \multicolumn{3}{|c|}{ Some period since 1950} & & & \\
\hline & $\begin{array}{l}\text { Phen- } \\
\text { oxy- } \\
\text { acids }\end{array}$ & $\begin{array}{l}\text { Chlo- } \\
\text { ro- } \\
\text { phe- } \\
\text { nols }\end{array}$ & $\begin{array}{l}\text { Non- } \\
\text { ex- } \\
\text { posed }\end{array}$ & $\begin{array}{l}\text { Phen- } \\
\text { oxy- } \\
\text { acids }\end{array}$ & $\begin{array}{l}\text { Chlo- } \\
\text { ro- } \\
\text { phe- } \\
\text { nols }\end{array}$ & $\begin{array}{l}\text { Non- } \\
\text { ex- } \\
\text { posed }\end{array}$ & $\begin{array}{l}\text { Phen- } \\
\text { oxy- } \\
\text { acids }\end{array}$ & $\begin{array}{c}\text { Chlo- } \\
\text { ro- } \\
\text { phe- } \\
\text { nols }\end{array}$ & $\begin{array}{c}\text { Non- } \\
\text { ex- } \\
\text { posed }\end{array}$ \\
\hline $\begin{array}{l}\text { Cases } \\
\text { Referents }\end{array}$ & $\begin{array}{l}28 \\
14\end{array}$ & $\begin{array}{l}8 \\
4\end{array}$ & $\begin{array}{l}27 \\
89\end{array}$ & $\begin{array}{l}8 \\
9\end{array}$ & $\begin{array}{l}7 \\
1\end{array}$ & $\begin{array}{l}22 \\
56\end{array}$ & $\begin{array}{l}5 \\
1\end{array}$ & $\begin{array}{l}5 \\
3\end{array}$ & $\begin{array}{r}59 \\
158\end{array}$ \\
\hline Risk ratio & 5.4 & & 0.8 & 2.4 & & 1.1 & & & $(1.0)$ \\
\hline
\end{tabular}


closed during the interviews, such as some individuals answering that phenoxy acids had been used in their neighborhood without their own active participation or some individuals not mentioning what preparation had been used but referring to spraying in their own garden with nicotine, etc. This analysis was merely a validation of the questionnaire with respect to exposure to phenoxy acids. About a fourfold increase in risk was demonstrated in all three studies, a finding indicating that no major change in the results was introduced by the interviewer.

For the further elucidation of a possible observational bias, all the subjects em- ployed in agriculture/forestry in the second soft-tissue sarcoma study and the malignant lymphoma study were divided into two groups, long- (ie, since the 1950s) and short-term farm/forestry work, and the risk ratios for exposed and nonexposed individuals employed in agriculture/ forestry were calculated with nonexposed subjects in other occupations as the reference group (tables $2 \& 3$ ). For the nonexposed individuals occupied in agriculture/forestry during the whole period since 1950 , a risk ratio of 1.2 and 0.8 was obtained for the two studies, respectively, and for those employed for only some period a risk ratio of 1.0 was

Table 4. Exposure frequencies $(\%)$ to different agents among the cases and referents of the total sample and after exclusion of those exposed to phenoxy acids and chlorophenols, respectively.

\begin{tabular}{|c|c|c|c|c|}
\hline \multirow{3}{*}{ Agents, etc } & \multicolumn{4}{|c|}{ Exposure frequency } \\
\hline & \multirow{2}{*}{ Cases } & \multicolumn{3}{|c|}{ Referents } \\
\hline & & $\begin{array}{l}\text { Sarcoma I } \\
\text { study }\end{array}$ & $\begin{array}{l}\text { Malignant } \\
\text { lymphoma } \\
\text { study }\end{array}$ & $\begin{array}{l}\text { Total, } \\
\text { both studies }\end{array}$ \\
\hline $\begin{array}{l}\text { Total material } \\
\text { (number of subjects in parentheses) }\end{array}$ & $(154)$ & $(206)$ & (335) & (541) \\
\hline $\begin{array}{l}\text { Asbestos } \\
\text { Chlorophenols (high-grade) } \\
\text { Chlorophenols (low-grade) } \\
\text { Dichloro-diphenyl-trichloro-ethane (DDT) } \\
\text { Drugs } \\
\text { Antihypertensive drugs } \\
\text { Clofibrate } \\
\text { Glass fibers } \\
\text { Mercury seed dressings } \\
\text { Motor saws } \\
\text { Organic solvents (high-grade) } \\
\text { Organic solvents (low-grade) } \\
\text { Phenoxy acids } \\
\text { Phenoxy acids and chlorophenols (high-grade) }\end{array}$ & $\begin{array}{l}10.4 \mathrm{a} \\
3.9 \\
8.4 \\
5.8 \mathrm{~b} \\
\\
31.6 \mathrm{c} \\
1.3 \\
11.0 \\
5.8 \mathrm{a} \\
10.4 \\
18.2 \\
10.4 \\
7.1 \\
11.0\end{array}$ & $\begin{array}{c}4.9 \\
2.9 \\
6.8 \\
6.8^{\mathrm{d}} \\
\text { Not analyzed } \\
\text { Not analyzed } \\
11.2^{\mathrm{b}} \\
3.4 \\
19.9 \mathrm{~b} \\
\text { Not analyzed } \\
\text { Not analyzed } \\
8.3 \\
10.7\end{array}$ & $\begin{array}{r}6.3 \\
2.7 \\
7.8 \\
7.8 \\
22.6 \\
0.9 \\
11.3 \\
3.0 \\
20.9 \\
15.2 \\
11.6 \\
7.8 \\
10.1\end{array}$ & $\begin{array}{r}5.7 \\
2.8 \\
7.4 \\
7.4 \\
- \\
-\overline{11.3} \\
3.1 \\
20.5 \\
- \\
\overline{7.9} \\
10.4\end{array}$ \\
\hline $\begin{array}{l}\text { Material after exclusion of those exposed } \\
\text { to phenoxy acids } \\
\text { (number of subjects in parentheses) }\end{array}$ & $(143)$ & $(189)$ & (309) & (498) \\
\hline $\begin{array}{l}\text { Dichloro-diphenyl-trichloro-ethane (DDT) } \\
\text { Mercury seed dressings } \\
\text { Motor saws }\end{array}$ & $\begin{array}{l}2.1 \\
4.2 \\
6.5\end{array}$ & $\begin{array}{r}5.3 \\
3.2 \\
14.1\end{array}$ & $\begin{array}{r}3.6 \\
2.9 \\
15.2\end{array}$ & $\begin{array}{r}4.2 \\
3.0 \\
14.8\end{array}$ \\
\hline $\begin{array}{l}\text { Material after exclusion of those exposed } \\
\text { to chlorophenols (high-grade) } \\
\text { (number of subjects in parentheses) }\end{array}$ & $(148)$ & $(200)$ & (326) & $(526)$ \\
\hline $\begin{array}{l}\text { Asbestos } \\
\text { Glass fibers }\end{array}$ & $\begin{array}{r}9.5 \\
10.1\end{array}$ & $\begin{array}{l}4.0 \\
9.2\end{array}$ & $\begin{array}{l}6.2 \\
8.3\end{array}$ & $\begin{array}{l}5.3 \\
8.7\end{array}$ \\
\hline
\end{tabular}

a One subject did not know about exposure.

b Two subjects did not know about exposure.

c Three subjects did not know about exposure.

d Four subjects did not know about exposure. 
calculated for both studies. If the exposure of cases was considerably exaggerated and the exposure of the referents highly underestimated, a value far below 1.0 would have been obtained in the callculation of risk ratios of nonexposed individuals in agriculture/forestry as compared to other occupations. The obtained risk ratios of about 1.0 indicate that no sulbstantial distortion in the observation of exposure to phenoxy acids could be pres- ent in the studies. Furthermore, the rather similar risk ratios determined for nonexposed subjects among individuals with shorit- and long-term occupation in agriculture/forestry in the two studies indicated that there could hardly be any secondary recall about occupation by individuals with a short time of employment [as suggested (3)] which should have disqualified the technique (1) for evaluating abservational bias in the studies. Chloro-

Table 5. Number of colon cancer cases and referents exposed to phenoxy acids and chlorophenol.

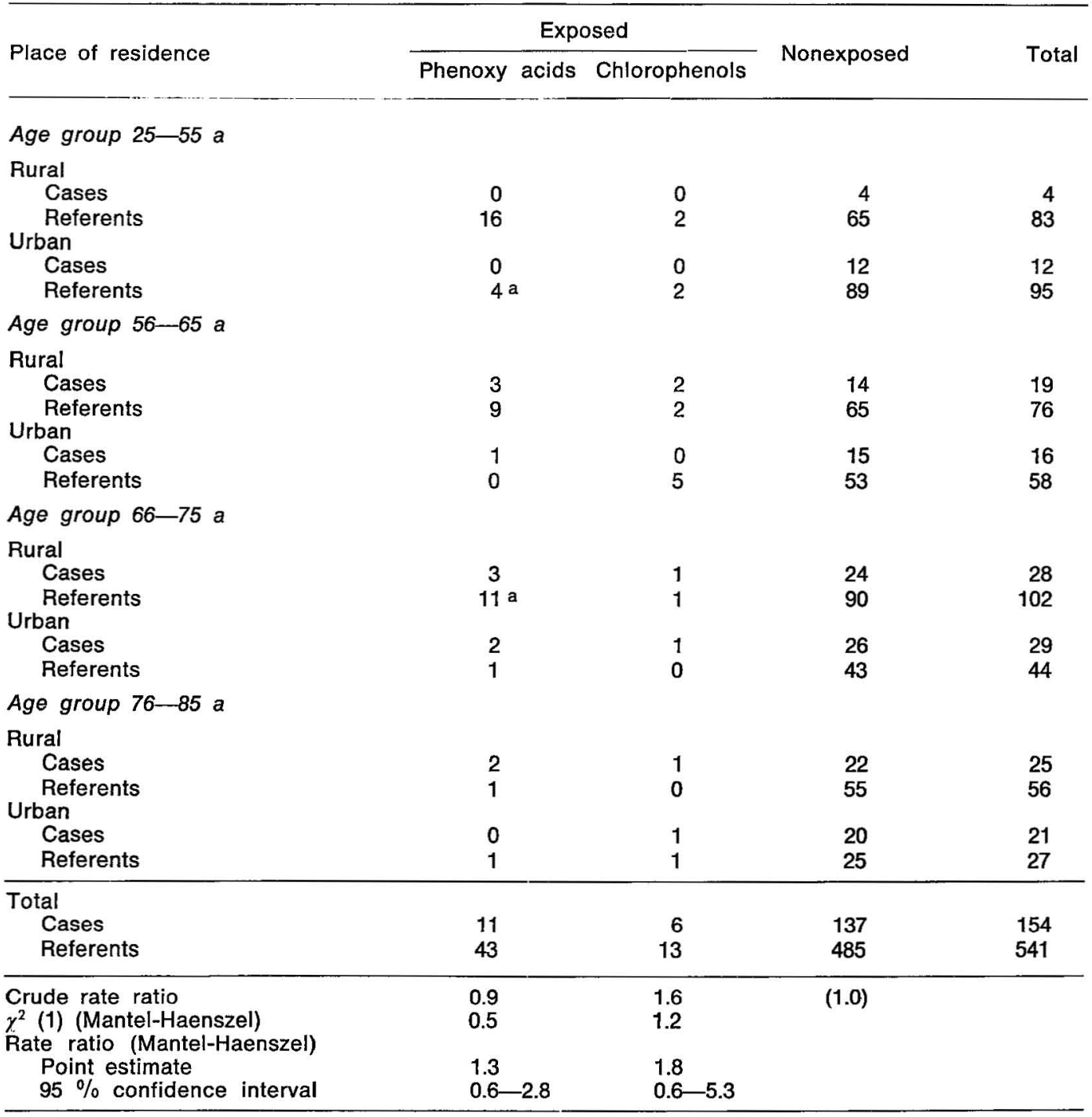

a One control exposed both to phenoxy acids and chlorophenols is included among the subjects exposed to phenoxy acids. 
phenol exposure is more common in other occupations, such as woodwork, including saw mills. With the same technique the risk ratios were also calculated for nonexposed subjects employed in agriculture/ forestry/woodwork without any distortion of the results (tables $2 \& 3$ ).

\section{Colon cancer study}

The cases of the colon cancer study consisted of 157 men. Three $(1.9 \%)$ of them did not answer the questionnaire. Out of the 541 referents, 206 were derived from the soft-tissue sarcoma study and 335 from the malignant lymphoma study; thus all the referents from the two studies were used. Sixty-five $(41 \%)$ cases and $245(45 \%)$ referents were deceased.

Exposure to various agents is presented in table 4 . Of the cases and referents 11.0 and $10.4 \%$, respectively, had been exposed to phenoxy acids or chlorophenols. Table 5 shows the risk ratios for exposure to phenoxy acids and chlorophenols. Stratification was made for age, vital status, and place of residence (urban vs rural domicile).

Phenoxy acids. Exposure to phenoxy acids gave a risk ratio (point esimate) of 1.3 $\left(\chi^{2}=0.5 ; 95 \%\right.$ confidence interval $0.6-$ 2.8 ; ie, no significant association was observed.

Chlorophenols. No obvious difference between cases and referents was found for low-grade exposure to chlorophenols although high-grade exposure formally gave a risk ratio of $1.8\left(\chi^{2}=1.2 ; 95 \%\right.$ confidence interval 0.6-5.3), which was not significant, however.

Other exposures. Exposure to various other agents is listed in table 4. Details about exposure to organic solvents, smoking habits, and use of antihypertensive drugs were supplemented over the phone if necessary. Use of antihypertensive drugs was somewhat more common among the colon cancer patients than among the referents. No significant difference between cases and referents was shown for organic solvents, dichloro-diphenyl-trichloro-ethane (DDT), glass fiber, and smoking. Exposure to mercury seed dressings covaried with exposure to phenoxy acids. The use of motor saws was less common among the colon cancer patients than among the referents. Exposure to asbestos was analyzed in more detail.

Asbestos. The answers regarding exposure to asbestos were not supplemented over the phone for more details about work procedures, exposure times, latency periods, etc, since detailed information about such exposure was not the primary aim of the studies. The one case and three referents who did not answer the question were excluded from the analysis. According to table 6 the risk ratio was calculated to be

Table 6. Number of cases and referents exposed to asbestos.

\begin{tabular}{|c|c|c|}
\hline Place of residence & Exposed & Nonex \\
\hline \multicolumn{3}{|l|}{$\begin{array}{l}\text { Age group } 25-55 \text { a } \\
\text { Rural }\end{array}$} \\
\hline Cases & 1 & 3 \\
\hline Referents & 6 & 76 \\
\hline \multicolumn{3}{|l|}{ Urban } \\
\hline Cases & 1 & 11 \\
\hline Referents & 3 & 91 \\
\hline \multirow{2}{*}{\multicolumn{3}{|c|}{$\begin{array}{l}\text { Age group } 56-65 \text { a } \\
\text { Rural }\end{array}$}} \\
\hline & & \\
\hline Cases & 2 & 17 \\
\hline Referents & 4 & 72 \\
\hline \multicolumn{3}{|l|}{ Urban } \\
\hline Cases & 2 & 14 \\
\hline \multirow{2}{*}{\multicolumn{3}{|c|}{$\begin{array}{l}\text { Age group } 66-75 \text { a } \\
\text { Rural }\end{array}$}} \\
\hline & & \\
\hline Cases & 2 & 26 \\
\hline Referents & 4 & 97 \\
\hline \multicolumn{3}{|l|}{ Urban } \\
\hline Cases & 5 & 24 \\
\hline Referents & 1 & 43 \\
\hline \multirow{2}{*}{\multicolumn{3}{|c|}{$\begin{array}{l}\text { Age group } 76-85 \text { a } \\
\text { Rural }\end{array}$}} \\
\hline & & \\
\hline Cases & 2 & 22 \\
\hline Referents & 4 & 52 \\
\hline \multicolumn{3}{|l|}{ Urban } \\
\hline Cases & 1 & 20 \\
\hline Referents & 3 & 24 \\
\hline \multicolumn{3}{|l|}{ Total } \\
\hline Cases & 16 & 137 \\
\hline Referents & 31 & 507 \\
\hline $\begin{array}{l}\text { Crude rate ratio } \\
\text { Standardized mortality }\end{array}$ & 1.9 & $(1.0)$ \\
\hline ratio, SMR & 1.8 & \\
\hline $\begin{array}{l}\text { Standardized rate } \\
\text { ratio, SRR }\end{array}$ & 2.9 & \\
\hline$\chi^{2}$ (1) (Mantel-Haenszel) & 3.5 & \\
\hline $\begin{array}{l}\text { Rate ratio (Mantel- } \\
\text { Haenszel) }\end{array}$ & & \\
\hline Point estimate & 1.9 & \\
\hline $95 \%$ confidence interval & $1.0-3.6$ & \\
\hline
\end{tabular}


$1.9\left(\chi^{2}=3.5 ; 95 \%\right.$ confidence interval $1.0-3.6)$.

Utilizing colon cancer as another reference entity

The previous studies of cases with softtissue sarcoma (11) or malignant lymphoma (10) with their residence in the region of the Department of Oncology in Umeå were evaluated using the colon cancer patients from the same population source as another reference entity. All the individuals were thereby stratified ac- cording to possible confounders such as place of residence (urban or rural domicile) and age. Tables 7 and 8 show about a fivefold increase in the risk $(p<0.001)$ for soft-tissue sarcoma and malignant lymphoma for cases exposed to phenoxy acids or chlorophenols, ie, about the same risks as in the published studies when matched referents from the population were used.

\section{Discussion}

One possible reason for misleading results in case-referent studies could be that cases

Table 7. Distribution of soft tissue sarcoma cases in northern Sweden (11) and colon cancer referent patients according to exposure history, place of residence, and age group.

\begin{tabular}{|c|c|c|c|c|}
\hline \multirow[b]{2}{*}{ Place of residence } & \multicolumn{2}{|c|}{ Exposed } & \multirow[b]{2}{*}{ Nonexposed } & \multirow[b]{2}{*}{ Total } \\
\hline & $\begin{array}{l}\text { Phenoxy } \\
\text { acids }\end{array}$ & $\begin{array}{l}\text { Chloro- } \\
\text { phenols }\end{array}$ & & \\
\hline \multicolumn{5}{|l|}{ Age group $25-55$ a } \\
\hline \multicolumn{5}{|l|}{ Rural } \\
\hline Cases & 2 & 1 & 2 & 5 \\
\hline Referents & 0 & $\tilde{u}$ & 4 & 4 \\
\hline \multicolumn{5}{|l|}{ Urban } \\
\hline Cases & 1 & 1 & 11 & 13 \\
\hline Referents & 0 & 0 & 12 & 12 \\
\hline \multicolumn{5}{|l|}{ Age group $56-65$ a } \\
\hline \multicolumn{5}{|l|}{ Rural } \\
\hline Cases & 3 & 2 & 3 & 8 \\
\hline Referents & 3 & 2 & 14 & 19 \\
\hline \multicolumn{5}{|l|}{ Urban } \\
\hline Cases & 1 & 0 & 4 & 5 \\
\hline Referents & 1 & 0 & 15 & 16 \\
\hline \multicolumn{5}{|l|}{ Age group $66-75$ a } \\
\hline \multicolumn{5}{|l|}{ Rural } \\
\hline Cases & 3 & 2 & 6 & 11 \\
\hline Referents & 3 & 1 & 24 & 28 \\
\hline \multicolumn{5}{|l|}{ Urban } \\
\hline Cases & 0 & 0 & 3 & 3 \\
\hline Referents & 2 & 1 & 26 & 29 \\
\hline \multicolumn{5}{|l|}{ Age group $76-85$ a } \\
\hline \multicolumn{5}{|l|}{ Rural } \\
\hline Cases & 2 & 0 & 4 & 6 \\
\hline \multirow{2}{*}{\multicolumn{5}{|c|}{ Urban }} \\
\hline & & & & \\
\hline $\begin{array}{l}\text { Cases } \\
\text { Referents }\end{array}$ & 1 & 0 & 0 & 1 \\
\hline Referents & 0 & 1 & 20 & 21 \\
\hline \multicolumn{5}{|l|}{ Total } \\
\hline Cases & 13 & 6 & 33 & 52 \\
\hline Referents & 11 & 6 & 137 & 154 \\
\hline \multirow{2}{*}{\multicolumn{5}{|c|}{$\begin{array}{l}\text { Crude rate ratio } \\
\chi^{2}(1) \text { (Mantel-Haenszel) }\end{array}$}} \\
\hline & 13.1 & 5.4 & & \\
\hline $\begin{array}{l}\text { Rate ratio (Mantel-Haenszel) } \\
\text { Point estimate }\end{array}$ & 5.5 & 5.4 & & \\
\hline $95 \%$ confidence interval & $2.2-13.8$ & $1.3-22.5$ & & \\
\hline
\end{tabular}


have a tendency to pay more attention to questions about previous chemical exposure than their referents or that the interviewer shows greater interest in the cases than the referents. The results obtained from a reconsideration of earlier studies show that there was no substantial difference in the exposure frequencies as obtained through questionnaires only or from questionnaires with a supplementary telephone interview. The value of the supplementary interview mainly seems to be that of removing misconceptions about questions and obtaining more detailed information on certain aspects. Thus the data on exposure was improved, but bias was hardly introduced, at least if one can judge from the present evaluation.

A bias in reporting exposure to phenoxy acids has been suggested by Cole (3) as the explanation of the results of these studies. It has also been suggested that people, especially cases, might not always directly recall jobs in agriculture/forestry, but first remember exposure to phenoxy acids and then, conditionally on that recall, also

Table 8. Distribution of malignant lymphoma patients (10) and colon cancer referent patients according to exposure history, place of residence, and age group. Five patients with malignant lymphoma exposed both to phenoxy acids and chlorophenols included among individuals exposed to phenoxy acids.

\begin{tabular}{|c|c|c|c|c|}
\hline \multirow[b]{2}{*}{ Place of residence } & \multicolumn{2}{|c|}{ Exposed } & \multirow[b]{2}{*}{ Nonexposed } & \multirow[b]{2}{*}{ Total } \\
\hline & $\begin{array}{l}\text { Phenoxy } \\
\text { acids }\end{array}$ & $\begin{array}{l}\text { Chloro- } \\
\text { phenols }\end{array}$ & & \\
\hline \multicolumn{5}{|l|}{ Age group $25-55$ a } \\
\hline $\begin{array}{l}\text { Rural } \\
\text { Cases } \\
\text { Referents }\end{array}$ & $\begin{array}{l}9 \\
0\end{array}$ & $\begin{array}{l}1 \\
0\end{array}$ & $\begin{array}{r}15 \\
4\end{array}$ & $\begin{array}{r}25 \\
4\end{array}$ \\
\hline $\begin{array}{l}\text { Urban } \\
\quad \text { Cases } \\
\text { Referents }\end{array}$ & $\begin{array}{l}5 \\
0\end{array}$ & $\begin{array}{l}5 \\
0\end{array}$ & $\begin{array}{l}20 \\
12\end{array}$ & $\begin{array}{l}30 \\
12\end{array}$ \\
\hline \multicolumn{5}{|l|}{ Age group $56-65$ a } \\
\hline $\begin{array}{l}\text { Rural } \\
\text { Cases } \\
\text { Referents }\end{array}$ & $\begin{array}{l}8 \\
3\end{array}$ & $\begin{array}{l}5 \\
2\end{array}$ & $\begin{array}{l}12 \\
14\end{array}$ & $\begin{array}{l}25 \\
19\end{array}$ \\
\hline $\begin{array}{l}\text { Urban } \\
\text { Cases } \\
\text { Referents }\end{array}$ & $\begin{array}{l}3 \\
1\end{array}$ & $\begin{array}{l}2 \\
0\end{array}$ & $\begin{array}{l}12 \\
15\end{array}$ & $\begin{array}{l}17 \\
16\end{array}$ \\
\hline \multicolumn{5}{|l|}{ Age group $66-75$ a } \\
\hline $\begin{array}{l}\text { Cases } \\
\text { Referents } \\
\text { Urban }\end{array}$ & $\begin{array}{r}10 \\
3\end{array}$ & $\begin{array}{l}2 \\
1\end{array}$ & $\begin{array}{l}17 \\
24\end{array}$ & $\begin{array}{l}29 \\
28\end{array}$ \\
\hline $\begin{array}{l}\text { Cases } \\
\text { Referents }\end{array}$ & $\begin{array}{l}2 \\
2\end{array}$ & $\begin{array}{l}2 \\
1\end{array}$ & $\begin{array}{l}12 \\
26\end{array}$ & $\begin{array}{l}16 \\
29\end{array}$ \\
\hline \multicolumn{5}{|l|}{ Age group $76-85$ a } \\
\hline $\begin{array}{l}\text { Rural } \\
\text { Cases } \\
\text { Referents }\end{array}$ & $\begin{array}{l}3 \\
2\end{array}$ & $\begin{array}{l}3 \\
1\end{array}$ & $\begin{array}{l}10 \\
22\end{array}$ & $\begin{array}{l}16 \\
25\end{array}$ \\
\hline $\begin{array}{l}\text { Urban } \\
\text { Cases } \\
\text { Referents }\end{array}$ & $\begin{array}{l}1 \\
0\end{array}$ & $\begin{array}{l}0 \\
1\end{array}$ & $\begin{array}{l}10 \\
20\end{array}$ & $\begin{array}{l}11 \\
21\end{array}$ \\
\hline $\begin{array}{l}\text { Total } \\
\text { Cases } \\
\text { Referents } \\
\end{array}$ & $\begin{array}{l}41 \\
11 \\
\end{array}$ & $\begin{array}{r}20 \\
6 \\
\end{array}$ & $\begin{array}{l}108 \\
137 \\
\end{array}$ & $\begin{array}{l}169 \\
154 \\
\end{array}$ \\
\hline $\begin{array}{l}\text { Crude rate ratio } \\
\chi^{2}(1) \text { (Mantel-Haenszel) } \\
\text { Rate ratio (Mantel-Haenszel) }\end{array}$ & $\begin{array}{r}4.7 \\
15.9\end{array}$ & $\begin{array}{l}4.2 \\
9.4\end{array}$ & $(1.0)$ & \\
\hline $\begin{array}{l}\text { Point estimate } \\
95 \% \text { confidence interval }\end{array}$ & $\begin{array}{l}4.5 \\
2.2-9.5\end{array}$ & $\begin{array}{l}4.6 \\
1.7-12.1\end{array}$ & & \\
\hline
\end{tabular}


remember earlier jobs. Such a situation would disqualify the special technique (1) used in these studies to evaluate observational bias. Although such a suggestion seems rather unlikely and invented ad hoc in testimony (3) during a cross-examination about these studies (Environmental Protection Agency Hearings on 2, 4, 5trichlorophenoxy acetic acid and Silvex), it is nevertheless of interest to refute this idea by objective means through a further and more-detailed display of the data in reference to the observational bias technique. Thus, the subjects were divided into two groups, those who had been employed continuously since 1950 and those with only temporary employment. The risk ratio was found to be about 1.0 for both groups. It might be noted that the exposure frequency is borderline for the technique to function among the referents with short time occupation in agriculture/forestry in the soft-tissue sarcoma study (4). In the lymphoma study, however, there were relatively large numbers and adequate exposure frequencies. If the exposure of cases would have been exaggerated and that of the referents underestimated, a value far below 1.0 would have been obtained for the nonexposed individuals. At least the group occupied continuously in agriculture/forestry since 1950 cannot be suggested to recall their occupation conditionally on recall of exposure to phenoxy acids as suggested by Cole (3); ie, there seems to be no longer any reason to believe in any observational bias in these studies and there is obviously not any rationale for such a belief.

Risk ratios were also calculated with the colon cancer patients as referents. About the same increase was found in the risk for soft-tissue sarcoma and malignant lymphoma for cases exposed to phenoxy acids or chlorophenols as previously reported. This result again indicated that no substantial observational bias could exist in the studies, since individuals suffering from colon cancer should be expected to recall exposure similarly as others suffering from cancer and the debate about possible health hazards from phenoxy acids was perhaps even more vigorous at the time of the colon cancer study than it was during the period of the earlier studies. This situation is noteworthy since it has been suggested (3) that the great interest in the adverse effects of phenoxy acids might have influenced the recall of exposure of the case individuals in comparison to the referents.

The colon cancer study was not performed during quite the same period as the other studies. With the same reference entity this difference might slightly bias the estimate of risk ratios in the colon cancer study although not with respect to deceased subjects. All the investigations were performed during 1978-1980.

The etiology of colon cancer is not well known. Environmental factors are believed to be important. A positive correlation has been reported between the incidence of colon cancer and general nutritional pattern, fat and protein consumption, arteriosclerotic heart disease, and economic development (7). Support for the assumption that environmental factors are important is given by migrant studies. Populations immigrating from a low incidence area to a high incidence area assume the cancer risk of the latter $(6,25)$. Regarding diet, African populations with a high daily intake of fiber and a low intake of refined carbohydrates, as compared to the Western diet, have a lower incidence of colon cancer than in Western countries (26). Bile acids and their degradation products secreted in response to ingested fat are believed to promote cancer $(2,13)$. Furthermore diet determines, in the intestine, the composition of the microbial flora which might produce carcinogenic or cocarcinogenic compounds from food or gastrointestinal secretions $(5,12)$. Chronic long-standing inflammatory disease such as ulcerative colitis (20), granulomatous colitis (15), and adenomatous polyps in the colon (24) may all sometimes be precursors of colon carcinoma.

The main purpose of this study was to evaluate a possible relationship between colon cancer and exposure to phenoxy acids or chlorophenols and to check validity aspects of earlier studies. No significant association between this cancer form and exposure to phenoxy acids or chlorophenols was shown. On the other hand Oliver et al (21) reported, among other diseases, an overall excess of deaths from gastrointestinal cancer among patients treated with the phenoxy acid derivate clofibrate as compared to the two referent groups. The inquiries in this 
colon cancer investigation also included a question about the use of clofibrate. Its use was reported by two cases and three referents, all of whom, however, had been exposed within 5 a prior to the diagnosis.

Among asbestios workers an excess of lung cancer, pleural and peritoneal mesothelioma, and cancer of the stomach, colon and rectum has been reported $(22,23)$. For colon and rectum cancer the reported risk ratios were 2.1 and 2.9 , respectively, in two cohorts (23). These results are in accordance with the findings of the present study. In the previous studies of soft-tissue sarcoma and malignant lymphoma no difference in exposure to asbestos was seen between cases and referents in spite of an intense debate and information about asbestos as a cause of cancer.

Regarding exposure to various other agents in table 4, no difference was seen between colon cancer cases and referents. Colon cancer is less common among physically active individuals (14), which is the situation for lumberjacks using motor saws. This can explain the fact that motorsaw use was less common among the colon cancer cases than among the referents. The use of antihypertensive drugs was somewhat more common among the colon cancer patients than among the referents.

In summary these analyses showed that the previously reported associations between exposure to phenoxy acids or chlorophenols and soft-tissue sarcoma and malignant lymphoma cannot to any essential degree be explained by observational bias in the studies. Regarding colon cancer, no significant association was found for these chemicals, even though phenoxy acids and chlorophenols might be of some marginal importance for the etiology of colon cancer. Exposure to asbestos was excessive among the colon cancer patients as compared to the referents, a finding in agreement with previously reported results.

\section{Acknowledgments}

This work was supported by grants from the Research Foundation, Department of Oncology, University of Umeå, Sweden, and from the Swedish Work Environment Fund.

I am greatly indebted to Prof O Axelson,
Linköping, for his assistance with the methodological discussions and statistical analysis. I am also greatly obliged to Prof LG Larsson, Umeå, for his support of my work, to Dr M Simonsson, who carried out all the interviews, and finally to $\mathrm{Mr} \mathrm{L}$ Andersson and $\mathrm{Mr} \mathrm{H}$ King, Linköping, for their assistance with the statistical calculations.

\section{References}

1. Axelson O. A note on observational bias in case-referent studies in occupational health epidemiology. Scand $j$ work environ health 6 (1980) 80-82.

2. Burkitt DP. Epidemiology of cancer of the colon and rectum. Cancer 28 (1971) 3-13.

3. Cole P. Direct testimony before the Environmental Protection Agency of the United States of America, Washington D.C. Exhibit 860, 1980, pp 2-24.

4. Eriksson IM, Hardell L, Berg NO, Möller T, Axelson $O$. Soft-tissue sarcomas and exposure to chemical substances: A Casereferent study. Br $\mathrm{j}$ ind med 38 (1981) 2733 .

5. Goldin BR, Gorbach SL. The relationship between diet and fecal bacterial enzymes implicated in colon cancer. $J$ natl cancer inst 57 (1976) $371-375$.

6. Haenszel W. Cancer mortality among the foreign-born in the United States. $J$ natl cancer inst 26 (1961) 37-132.

7. Haenszel W, Correa P, Cuello C. Social class differences among patients with large-bowel cancer in Cali, Colombia. J natl cancer inst 54 (1975) 1031-1035.

8. Hardell L. Soft-tissue sarcoma and exposure to phenoxy acids - A clinical observation. Läkartidningen 74 (1977) 28532854.

9. Hardell L. Malignant lymphoma of histiocytic type and exposure to phenoxyacetic acids or chlorophenols. Lancet 1 (1979) 5556.

10. Hardell L, Eriksson M, Lenner P, Lundgren E. Malignant lymphoma and exposure to chemical substances, especially organic solvents, chlorophenols and phenoxy acids: A case-control study. Br j cancer 43 (1981) $169-176$.

11. Hardell L, Sandström A. Case-control study: Soft-tissue sarcomas and exposure to phenoxyacetic acids or chlorophenols. $\mathrm{Br} \mathrm{j}$ cancer 39 (1979) $711-717$.

12. Hill MJ. The role of colon anaerobes in the metabolism of bile acids and steroids and its relation to colon cancer. Cancer 36 (1975) 2387-2400.

13. IARC Intestinal Microecology Group. Dietary fibre, transit-time, faecal bacteria, steroids and colon cancer in 2 Scandinavian populations. Lancet 2 (1977) 201-311.

14. Jones FA. Godding EW. Management of constipation. Blackwell, London 1972, pp $156-158$. 
15. Lightdale CJ, Sternberg SS, Posner G, Sherlock P. Carcinoma complicating Chrohn's disease. Am j med 59 (1975) 262268.

16. Mantel $\mathrm{N}$, Haenszel W. Statistical aspects of the analysis of data from retrospective studies of disease. $\mathrm{J}$ natl cancer inst 32 (1959) $719-748$.

17. Miettinen OS. Components of the crude risk ratio. Am j epidemiol 96 (1972) 168172.

18. Miettinen OS. Standardization of risk ratios. Am j epidemiol 96 (1972) 383-388.

19. Miettinen OS. Estimability and estimation in case-referent studies. Am $j$ epidemiol 103 (1976) 226-235.

20. Morson BC. Cancer in ulcerative colitis. Gut 7 (1966) 425-426.

21. Oliver MF, Heady JA, Morris JN, Cooper J. WHO cooperative trial on primary prevention of ischemic heart disease using clofibrate to lower serum cholesterol:
Mortality follow-up. Lancet 2 (1980) 379385.

22. Selikoff IJ, Churg J, Hammond EC. Asbestos exposure and neoplasia. $\mathrm{J}$ am med assoc 188 (1964) 22-26.

23. Selikoff IJ, Hammond EC. Multiple risk factors in environmental cancer. In: Fraumeni JF Jr, ed. Persons at high risk of cancer: An approach to cancer etiology and control. Academic Press Inc, New York NY 1975, pp $467-483$.

24. Sherlock P, Lipkin M, Winawer SJ. Predisposing factors in carcinoma of the colon. Adv intern med 20 (1975) 121-150.

25. Stemmermann GN. Cancer of the colon and rectum discovered at autopsy in Hawaiian Japanese. Cancer 19 (1966) 15671572.

26. Walker ARP, Burkitt DP. Colon cancer: Epidemiology. Semin oncol 3 (1976) 341 350.

Received for publication: 22 January 1981 